\title{
The Narrator, the Expositor, and the Prompter in European Medieval Theatre, Edited by Philip Butter- worth
}

\section{G. Matteo Roccati}

\section{(2) OpenEdition}

\section{Journals}

\section{Édition électronique}

URL : http://journals.openedition.org/studifrancesi/5882

DOI : 10.4000/studifrancesi.5882

ISSN : 2421-5856

Éditeur

Rosenberg \& Sellier

\section{Édition imprimée}

Date de publication : 1 mai 2011

Pagination : 150

ISSN : 0039-2944

\section{Référence électronique}

G. Matteo Roccati, «The Narrator, the Expositor, and the Prompter in European Medieval Theatre, Edited by Philip Butter-worth », Studi Francesi [En ligne], 163 (LV | I) | 2011, mis en ligne le 30 novembre 2015, consulté le 10 janvier 2021. URL : http://journals.openedition.org/studifrancesi/5882 ; DOI : https:// doi.org/10.4000/studifrancesi.5882

Ce document a été généré automatiquement le 10 janvier 2021.

\section{cc) (†)}

Studi Francesi è distribuita con Licenza Creative Commons Attribuzione - Non commerciale - Non opere derivate 4.0 Internazionale. 


\title{
The Narrator, the Expositor, and the Prompter in European Medieval Theatre, Edited by Philip Butter- worth
}

\author{
G. Matteo Roccati
}

\section{RÉFÉRENCE}

The Narrator, the Expositor, and the Prompter in European Medieval Theatre, Edited by Philip BUTTER-WORTH, Turnhout, Brepols, 2007 («Medieval Texts and Cultures of Northern Europe», 17), XIV-346 pp.

1 Ce recueil est consacré aux figures et aux rôles de «narrateur/récitant/souffleur» dans le théâtre et comporte quatorze contributions relatives à différents pays et époques. Parmi elles, trois relèvent de la Rassegna. Peter HAPPÉ, Expositor Figures in Some Cycle Plays in French and German, pp.45-69, examine notamment les figures du Prescheur et du Meneur dans la Passion d'Arras et La Vengance Jesu Christ. Mario LongTin, Prompting the Action: The Prologue, the Messenger, and the Fool, pp. 191-209, étudie le rôle structurant des personnages du Prologue, du Messager et du Fol dans le Mystère de sainte Barbe en deux journées et les Mystères de la procession de Lille. Alan HINDLEY, 'La prédication par personnages'? Expositor Figures in the 'Moralités', pp. 265-288, passe en revue des exemples significatifs de la variété de personnages qui s'adressent directement au public et souligne leur importance dans la dimension didactique du genre. 